\title{
Strategiczna karta wyników w ocenie integracji przedsiębiorstw górniczych
}

\section{Wprowadzenie}

Integracja przedsiębiorstw górniczych postrzegana jest jako proces łączenia odrębnych podmiotów, charakteryzujących się różnymi aspektami swojej podmiotowości i działalności. Biorąc pod uwagę kierunki, intensywność i formę organizacyjno-prawną, rozróżniamy integrację funkcjonalną lub strukturalną.

Ze względu na kierunki wyróżniamy:

- integrację pionową w tył, czyli w kierunku dostawców, np. w kierunku dostawców maszyn,

- integrację pionową w przód, czyli w kierunku nabywców, np. w kierunku głębokości przerobu kopaliny,

- integrację poziomą w kierunku dziedzin pokrewnych, np. w kierunku eksploatacji złóż o innej charakterystyce,

- integrację przedsiębiorstw niepowiązanych branżowo (konglomeraty), np. przedsiębiorstwo eksploatujące węgiel integruje się z przedsiębiorstwem eksploatującym surowce skalne.

Ze względu na intensywność wyróżniamy:

- integrację całkowitą, w której integrowane przedsiębiorstwa tworzą jedno przedsiębiorstwo,

- quasi-integrację w formie umów, udziałów, porozumień.

\footnotetext{
* Dr hab. inż., prof. nadzw., Politechnika Wrocławska
} 
Ze względu na formę organizacyjno-prawną wyróżniamy fuzje i przejęcia (Johnson 2000).

Fuzja jest połączeniem w jedno przedsiębiorstwo dwóch lub więcej podmiotów na zasadzie łączenia kapitałów, wykupu gotówkowego akcji lub udziałów jednej z firm lub kombinacji powyższych działań.

Przejęciem jest określana transakcja, w której jedna z firm, zwykle większa, dokonuje wykupu akcji lub udziałów drugiego przedsiębiorstwa w celu włączenia go w swoje struktury. Przejęcia mogą mieć charakter przyjazny lub wrogi.

W ocenie integracji przedsiębiorstw uwzględniamy wiele wymiarów, spośród których można wyróżnić: profil biznesowy, analizę produkcji, technologii i zaopatrzenia, analizę wyników produkcji i kontroli, analizę środowiskową, prawną itp. Zasadą lub procedurą albo też standardem w ocenie integracji przedsiębiorstw jest analiza due diligence, tzn. badanie przeprowadzone z należytą starannością mające na celu dostarczenie informacji niezbędnych do przeprowadzenia pełnej integracji łączących się podmiotów (Johnson 2000; Fołtyn 2005; Kudełko 2009, 2011).

W ramach ogólnej zasady due diligence do oceny integracji przedsiębiorstw zaproponowano zmodyfikowaną metodę strategicznej karty wyników.

Strategiczna karta wyników (rys. 1) jest metodą zarządzania przez cele (balanced scorecard). Określenie to bazowało na przedstawionym poniżej tłumaczeniu poszczególnych słów (Kaplan i Norton 1996, 2006):

- balanced: zrównoważona, zbilansowana, kompleksowa, strategiczna,

- scorecard: karta wyników, karta osiagnięć, karta dokonań, tablica wyników.

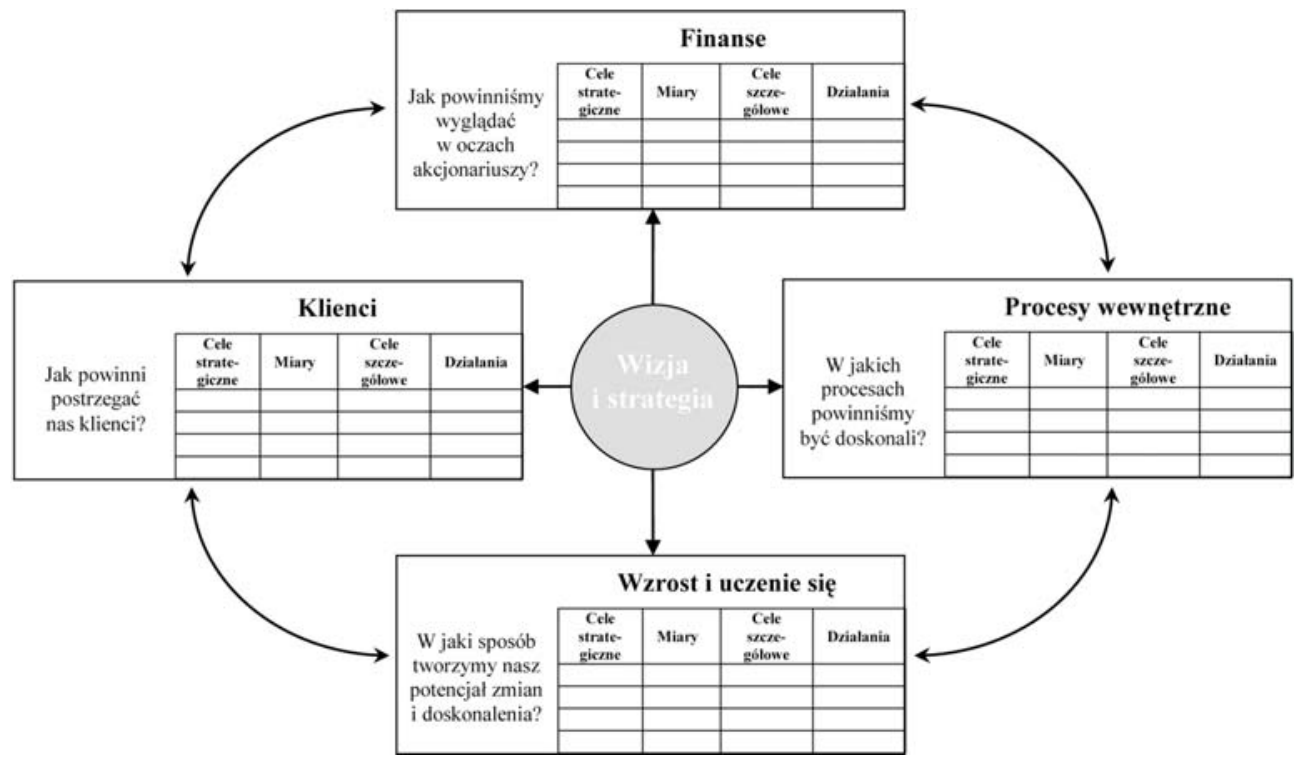

Rys. 1. Schemat ideowy strategicznej karty wyników

Źródło: Kaplan i Norton 2006

Fig. 1. Diagram of the balanced scorecard 
Istotę strategicznej karty wyników w odniesieniu do całej działalności przedsiębiorstwa górniczego obejmującego badania i rozwój, produkcję, logistykę, finanse i marketing, można przedstawić w następujących krokach:

1. Działanie przedsiębiorstwa charakteryzuje się poprzez analizę i sformułowanie celów w perspektywach (obszarach): finansowej, klienta, rozwoju i procesów wewnętrznych.

2. W każdej perspektywie formułuje się cele strategiczne, które mają być powiązane w sposób przyczynowo-skutkowy.

3. Każdy cel strategiczny jest następnie dekomponowany na cele operacyjne.

4. Cele mają być opisane miarami.

Wzorując się na strategicznej karcie wyników, odnoszącej się w klasycznej formie do całości przedsiębiorstwa górniczego, zaproponowano strategiczną kartę analizy i oceny integracji. Perspektywy integracyjne w określonych obszarach przedstawiono w tabeli 1. Czynniki charakteryzujące strategiczną kartę wyników można przedstawić następująco:

1. Karta oceny integracji przedsiębiorstw dotyczy fragmentu działalności przedsiębiorstwa macierzystego opisanego perspektywą rozwoju w strategicznej karcie wyników.

2. W karcie analizy i oceny integracji przedsiębiorstw wyróżnia się perspektywy: efektywnościową, zasobową, produktowo-rynkową i kompetencyjną.

3. W ramach zaproponowanych perspektyw wyróżnia się cele strategiczne. Zaleca się, aby cele były powiązane w sposób przyczynowo-skutkowy, ale dopuszcza się brak takiego powiązania. Dla takich powiązań odpowiednie algorytmy należy opisać w metryczce celów.

4. Cele integracyjne powinny być kompatybilne ze strategia przedsiębiorstwa, chociaż obejmują tylko fragment jego działalności. Należy je określać przyrostowo przy czym

Tabela 1. Strategiczna karta analizy i oceny integracji przedsiębiorstw

Table 1. Analysis and assessment of the companies' integration - strategic card

\begin{tabular}{|c|c|c|c|c|}
\hline \multirow{2}{*}{$\begin{array}{c}\text { Perspektywy } \\
\text { integracyjne }\end{array}$} & \multicolumn{2}{|c|}{ Integracja pionowa } & \multicolumn{2}{c|}{ Integracja pozioma } \\
\cline { 2 - 5 } Efektywnościowa & $\begin{array}{c}\text { Zwiększenie } \\
\text { sprzedaży }\end{array}$ & $\begin{array}{c}\text { Zmniejszenie } \\
\text { kosztów } \\
\text { zaopatrzenia }\end{array}$ & $\begin{array}{c}\text { Zwiększenie } \\
\text { sprzedaży }\end{array}$ & $\begin{array}{c}\text { Dywersyfikacja } \\
\text { ryzyka }\end{array}$ \\
\hline Zasobowa & Wzrost aktywów & Wzrost aktywów & $\begin{array}{c}\text { Wzrost aktywów } \\
\text { tym koncesje } \\
\text { złożowe }\end{array}$ & Wzrost aktywów \\
\hline $\begin{array}{c}\text { Produktowo- } \\
\text {-rynkowa }\end{array}$ & $\begin{array}{c}\text { Nowe produkty } \\
\text { Nowe rynki }\end{array}$ & $\begin{array}{c}\text { Stare produkty } \\
\text { Stare rynki }\end{array}$ & $\begin{array}{c}\text { Nowe produkty } \\
\text { Stare rynki }\end{array}$ & $\begin{array}{c}\text { Nowe produkty } \\
\text { Nowe rynki }\end{array}$ \\
\hline Kompetencyjna & Nowe kompetencje & Nowe kompetencje & Nowe kompetencje & Nowe kompetencje \\
\hline
\end{tabular}

Źródło: opracowanie własne 
wśród zmiennych opisujących cele wyróżnia się stymulanty i destymulanty. Z punktu widzenia efektywności integracji stymulanty (liczone przyrostowo) powinny być dodatnie, natomiast destymulanty powinny być ujemne.

5. Cele integracyjne są określone na podstawie uprzedniej analizy w wyróżnionych perspektywach i mają charakter indywidualny. W dalszej części artykułu przedstawiony zostanie ogólny zakres merytoryczny wyróżnionych perspektyw i formułowanych w nich celów.

\section{Perspektywa efektywnościowa}

Perspektywa efektywnościowa obejmuje obszar finansowy, ale także dotyczy wydajności pracy, produktywności maszyn i urządzeń, skali produkcji w tym progów rentowności, ochrony środowiska, zubożenia rudy (Dyczko 2002) itp. Rodzaj efektów integracji jest $\mathrm{w}$ dużym stopniu zdeterminowany kierunkiem integracji.

Efektów integracji pionowej w tył upatruje się w pewności, terminowości i kosztach zaopatrzenia w czynniki produkcji (maszyny, energia, materiały, urządzenia), natomiast efektów integracji w przód upatruje się w głębokim przerobie surowców, a tym samym dywersyfikacji produkcji, a także w nowych kanałach dystrybucji.

Efektów integracji poziomej pokrewnej upatruje się w zwiększeniu skali i doświadczenia, a także dyferencjacji produktów. Efekty integracji poziomej konglomeratowej mogą się przejawiać poprzez dywersyfikację i zmniejszenie ryzyka oraz uwzględnienie w strategii przedsiębiorstwa nowych produktów i usług. Podkreślić jednak należy, że efektywność integracji należy analizować indywidualnie dla każdego odrębnego przypadku.

W obszarze finansowym podstawowymi źródłami informacji są sprawozdania finansowe w tym bilans, rachunek zysków i strat oraz przepływy finansowe. W sensie ekonomicznym podstawowym celem oceny integracji jest wzrost wartości przedsiębiorstwa, jednakże warto posługiwać się także miernikami cząstkowymi, które ogólnie dzielimy na statyczne i dynamiczne (Butra i in. 2010; Wanielista 2002).

Przy zastosowaniu mierników statycznych nie uwzględniamy wartości pieniądza w czasie, posługujemy się zazwyczaj wartościami średniorocznymi oraz przychodami i kosztami.

Przy zastosowaniu mierników dynamicznych uwzględniamy wartości pieniądza w czasie oraz okres życia projektu odpowiadający średnioważonemu okresowi amortyzacji środków trwałych, a w rachunku posługujemy się wpływami i wydatkami.

Do mierników statycznych zaliczamy: zysk operacyjny, zysk netto, ekonomiczną wartość dodaną, operacyjną stopę zwrotu, stopę zwrotu kapitału własnego, okres zwrotu wydatków kapitałowych, progi rentowności, dźwignię operacyjną itp.

Do podstawowych mierników dynamicznych zalicza się wartość zaktualizowaną netto i wewnętrzną stopę zwrotu.

Jak wspomniano standardowym i syntetycznym celem działalności firmy, w tym także integracji przedsiębiorstw jest wzrost wartości firmy. W ogólnym przypadku możemy 
przyjąć, że wartość zintegrowanego przedsiębiorstwa jest sumą łączących się przedsiębiorstw (Jajuga K. i Jajuga T. 1998):

$$
W_{\text {int }}=W_{1}+W_{2}
$$

$\Leftrightarrow W_{\text {int }} \quad-$ wartość zintegrowanego przedsiębiorstwa, zł,

$W_{1}, W_{2}$ - odpowiednio wartość pierwszego i drugiego przedsiębiorstwa, zł.

Natomiast ryzyko mierzone odchyleniem standardowym od tych wartości możemy opisać wzorem:

$$
\sigma_{\text {int }}=\sqrt{W_{1}^{2} \cdot \sigma_{1}^{2}+W_{2}^{2} \cdot \sigma_{2}^{2}+2 W_{1} \cdot W_{2} \sigma_{1} \sigma_{2} \cdot w k_{12}}
$$

$\Leftrightarrow \sigma_{1}, \sigma_{2}-$ odchylenia standardowe wartości przedsiębiorstw,

$w k_{12}$ - współczynnik korelacji pomiędzy wartościami przedsiębiorstw.

Alfred Rappaport (Suszyński i in. 2007) efekty ekonomiczne integracji opisał następująco:

Wartość stworzona $w$ wyniku przejęcia $=$

$=$ wartość połaczonych przedsiębiorstw - odrębna wartość nabywcy + + odrębna wartość przedsiębiorstwa nabywajacego

Wartość stworzona dla nabywcy $=$

= maksymalna akceptowana cena zakupu-

- cena zaptacona za nabyte przedsiębiorstwo

Maksymalna cena zakupu $=$

= odrębna wartość przedsiębiorstwa nabywajacego -

- wartość synergii uzyskanych dzięki przejęciu

Wzory 1-5 mają charakter ogólny, a każda sytuacja integracyjna wymaga dostosowanego do niej opisu.

Szczególnym przypadkiem są zagraniczne projekty integracyjne, które należy analizować na dwóch poziomach (Buckley 2002):

- przyrostowych strumieni pieniężnych samego projektu,

- przyrostowych strumieni pieniężnych dostępnych firmie macierzystej.

W takiej sytuacji należy także uwzględnić:

- wkłady firmy macierzystej w postaci aportu rzeczowego,

- prognozowane zmiany kursów walut, 
- różnice w stawkach podatkowych w kraju firmy macierzystej i w kraju, w którym jest zlokalizowana firma integrowana,

- wysokość opłat za zarządzanie itp.

W perspektywie efektywności ekonomicznej korzystniej jest formułować cele nie w ogólnej, ale skonkretyzowanej postaci. Najczęściej jest to wartość sprzedaży i poziom kosztów ale także np. progi rentowności, wydajność pracy, produktywność maszyn itp. Szczegółowe określenie celów w perspektywie efektywnościowej pozwala sensownie je rozwijać i łączyć w sposób przyczynowo-skutkowy z celami określonymi w pozostałych perspektywach integracji przedsiębiorstw górniczych. Ogólne miary efektywności przedstawione powyżej mają zastosowanie dla wszystkich przedsiębiorstw, natomiast algorytmy obliczania wyróżnionych miar muszą być dostosowane do konkretnego przedsiębiorstwa górniczego będącego przedmiotem integracji (Sobczyk 2000).

\section{Perspektywa zasobowa}

Perspektywa zasobowa dotyczy:

- aktywów i pasywów opisanych w bilansie nabywanego przedsiębiorstwa górniczego,

- zasobów pozabilansowych jak np. monopol naturalny, segment rynku, który obejmuje tradycyjnie jedno przedsiębiorstwo.

Dla przedsiębiorstw górniczych i surowcowych istotne są aktywa geologiczno-górnicze a w szczególności zasoby złóż kopalin.

Z punktu widzenia integracji przedsiębiorstw górniczych istotnym czynnikiem jest wartość złóż objętych posiadanymi koncesjami. Zależą one w szczególności od:

1) lokalizacji złoża i związanych z nią aspektów technicznych, ekonomicznych, politycznych, społecznych itp.,

2) charakterystyki geologiczno-górniczej złoża, ochrony zasobów i ochrony środowiska,

3) rozpoznania złoża w odpowiednich kategoriach,

4) stopnia zagospodarowania złoża,

5) wartości zasobów.

Wymiary ujęte w punktach 1-4 przy zakupie złóż należy rozwinąć w sposób kompletny i szczegółowy opisany w odpowiedniej literaturze przedmiotu (Wanielista i Wirth 2008). W zakresie obliczania wartości złóż in situ nie przedstawiono dotychczas standardowej, powszechnie akceptowalnej metody. W większości przypadków tzw. wartość fundamentalną złoża utożsamia się z wartością projektu jego zagospodarowania i eksploatacji mierzoną wartością zaktualizowaną netto projektu. Wyróżniono wartość fundamentalną złoża, wartość złoża dla nabywcy (inwestora) oraz cenę złoża, tj. wartość złoża dla jego właściciela. Przedstawione kategorie ekonomiczne opisują wzory:

$$
V_{z \nmid o ́ \dot{z}}=\sum_{t=0}^{T} \frac{N C F_{t}}{(1+d)^{t}}+V_{o p c}
$$




$$
P_{z t o ́ z}=V_{z t o ́ z} \cdot R \cdot K
$$

lub

$$
V_{i n w}=V_{z l o ́ z}-P_{z l o ́ z}
$$

$\stackrel{\leftrightarrow}{\sharp} V_{z l o ́ z}-$ wartość fundamentalna złoża, zł,

$T \quad$ - okres eksploatacji złoża, lata,

$N C F_{t}$ - saldo przepływów pieniężnych netto w $t$-tym roku, zz/rok,

$d \quad-$ stopa dyskontowa,

$V_{o p c}$ - wartość opcyjna złoża (wartość mierząca elastyczność projektu), zł,

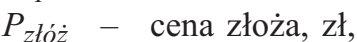

$R \quad$ - współczynnik określający część wartości fundamentalnej złoża przypadający jego właścicielom wyrażony ułamkiem dziesiętnym,

$K \quad$ - współczynnik korygujący wartość złoża ze względu na jego otoczenie transakcyjne, kontekstowe i lokalizację złoża wyrażony ułamkiem dziesiętnym,

$V_{i n w}$ - wartość złoża dla inwestora, zł.

Pierwszym kryterium oceny integracji przedsiębiorstw górniczych jest posiadanie lub realna możliwość uzyskania koncesji na poszukiwanie, rozpoznanie i/lub użytkowanie złóż. Następnym istotnym kryterium oceny jest lokalizacja złóż (Wanielista 2002). W zakresie lokalizacji ogólnej, analizuje się w szczególności następujące elementy otoczenia projektu:

- stabilność polityczną kraju, w którym ma być realizowany projekt,

- stabilność społeczną,

- powiązania międzynarodowe, w tym przynależność do organizacji międzynarodowych politycznych, gospodarczych, wojskowych,

- bezpieczeństwo realizacji i eksploatacji projektu,

- ogólny klimat inwestycyjny,

- gwarancje państwowe,

- interwencjonizm państwowy,

- dotacje państwowe,

- system podatkowy,

- możliwość transferu zysków,

- odległość rynków zbytu produktów generowanych przez projekt,

- uwarunkowania ekologiczne,

- inne uwarunkowania - znaczące z punktu widzenia realizacji projektu.

Mikroekonomiczna analiza jest ukierunkowana na szczegółową lokalizację projektu, a w szczególności na jego infrastrukturę.

W zakresie lokalizacji szczegółowej istotne znaczenie mają następujące czynniki:

- możliwość integracji z innymi jednostkami inwestora, 
- dostępność dróg transportowych, w tym taboru:

- lotniczego,

- kolejowego,

- wodnego,

- drogowego (kołowego),

- rurociagowego;

- dostępność zasileń w czynniki produkcji, w tym:

- w surowce i materiały,

- maszyny i urządzenia,

- energię,

- siłę roboczą;

- dostępność uzbrojenia terenu, w tym:

- doprowadzenia gazu,

- doprowadzenia energii elektrycznej,

- zaopatrzenia w wodę,

- odprowadzenia ścieków,

- usuwania odpadów,

- systemu łączności;

- warunki bezpiecznego prowadzenia robót,

- dogodność warunków klimatycznych i właściwości terenu,

- dostępność do terenu rezerwowego na ewentualną rozbudowę projektu,

- przepisy lokalne,

- koszty terenu,

a także inne czynniki charakterystyczne dla konkretnego projektu górniczego, np.:

- wielkość zasobów,

- jakość zasobów (zawartość składników użytecznych, spełnienie norm, warunki zalegania itp.),

- zagrożenia:

- tąpaniami,

- gazami,

- woda,

- chemizmem wód,

oraz inne czynniki charakterystyczne dla tego typu projektów.

\section{Perspektywa produkcyjno-rynkowa}

Cele integracyjne określa się z punktu widzenia przedsiębiorstwa macierzystego. Ogólnie owe cele plasują się w macierzy H.J. Ansoffa (1965), przy czym wyróżnionymi wymiarami są produkt i rynek, dla których określa się miary celów. 


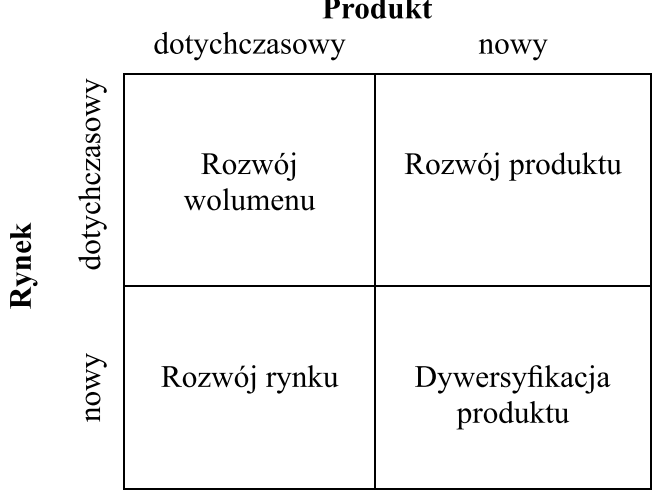

Rys. 2. Strategie produktowo-rynkowe

Źródło: opracowanie własne na podstawie Ansoffa 1965

Fig. 2. Product - market strategies

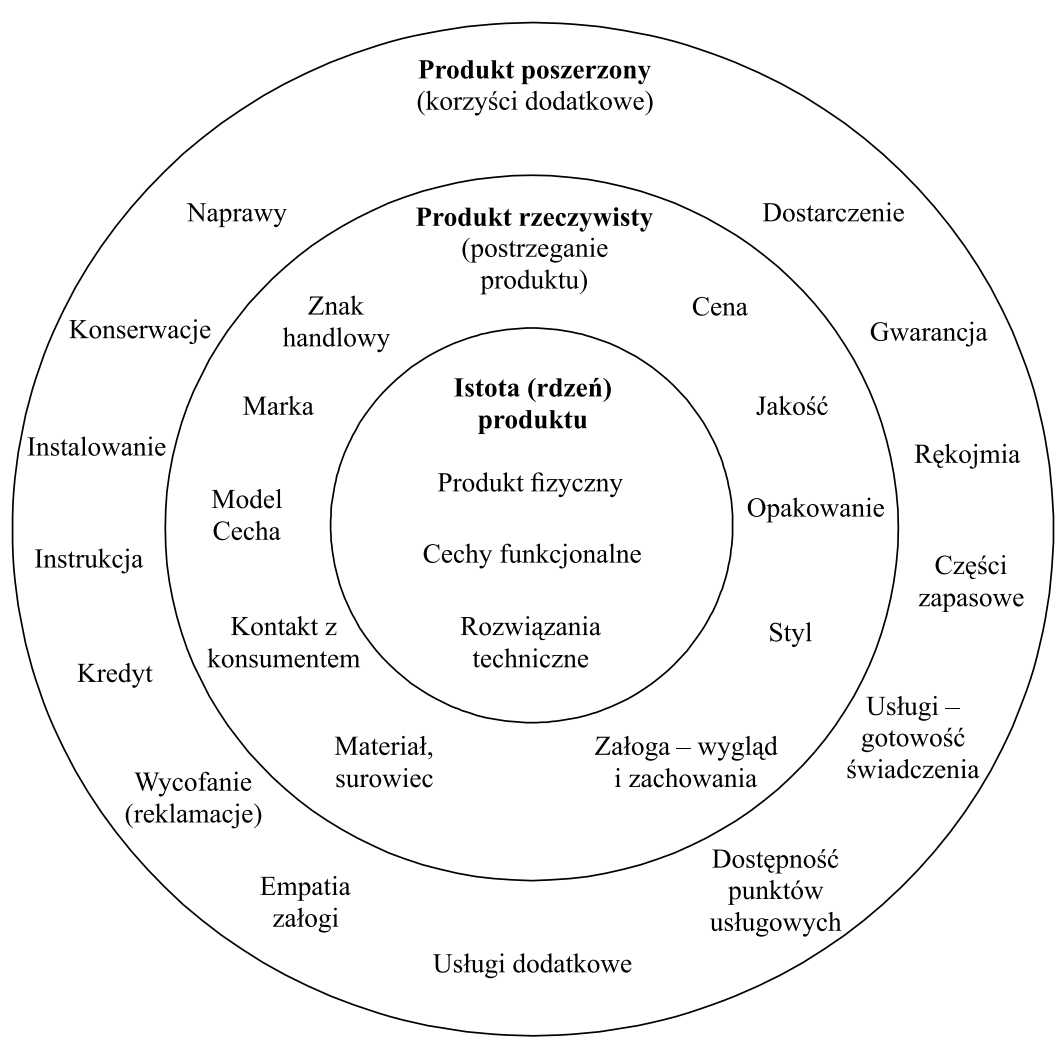

Rys. 3. Charakterystyka produktu Źródło: Mruk i Rutkowski 2001

Fig. 3. Product characteristies 
Produkt jest towarem charakteryzowanym wielowymiarowo (rys. 3). Wyróżnia się (Mruk i Rutkowski 2001):

- produkt fizyczny określany przez jego cechy funkcjonalne i rozwiązania techniczne,

- produkt rzeczywisty - czyli produkt fizyczny, z elementami wzbogacającymi jego wartość użytkową; jest rezultatem postrzegania produktu (w usługach - podstawowa usługa i minimum związanych z nią oczekiwań, które muszą być spełnione),

- produkt poszerzony - czyli produkt rzeczywisty wzbogacony o korzyści dodatkowe związane z jego użytkowaniem; elementy różnicowania produktu (w usługach wzbogacenie produktu o cechy pozwalające odróżnić usługę od usług konkurencyjnych).

Rozwój wolumenu polega na zwiększaniu skali produkcji. Rozwój produktu polega zazwyczaj na strategii jego różnicowania. W strategii różnicowania produkt opisywany jest za pomocą dwóch zmiennych, a mianowicie szerokości oraz głębokości asortymentu. Na szerokość składają się różne linie produktów, natomiast na głębokość - typy produktów zawarte w jednej linii produktów.

Dywersyfikacja produktu występuje wówczas, gdy w wyniku integracji przedsiębiorstw górniczych uzyskują one koncesje na użytkowanie (eksploatację) kopalin w różnych sektorach, np. górnictwie skalnym i górnictwie rud.

Analiza produktu w perspektywie produktu musi uwzględniać jego jakość z punktu widzenia klienta i własnego punktu widzenia, tj. producenta (rys. 4 i 5). Perspektywę produktu należy analizować w powiązaniu z rynkami, na których są lub będą oferowane

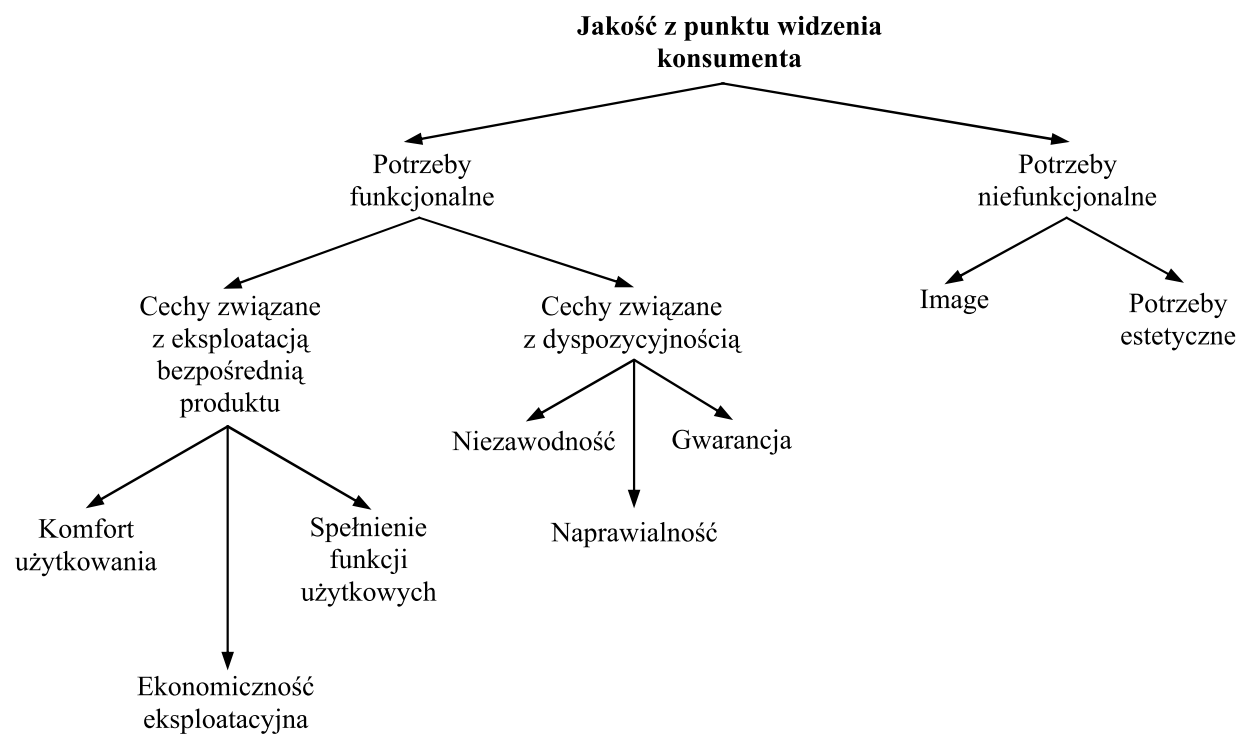

Rys. 4. Jakość z punktu widzenia klienta Źródło: Borucki i Urbaniak 1996

Fig. 4. Quality from the client perspective 


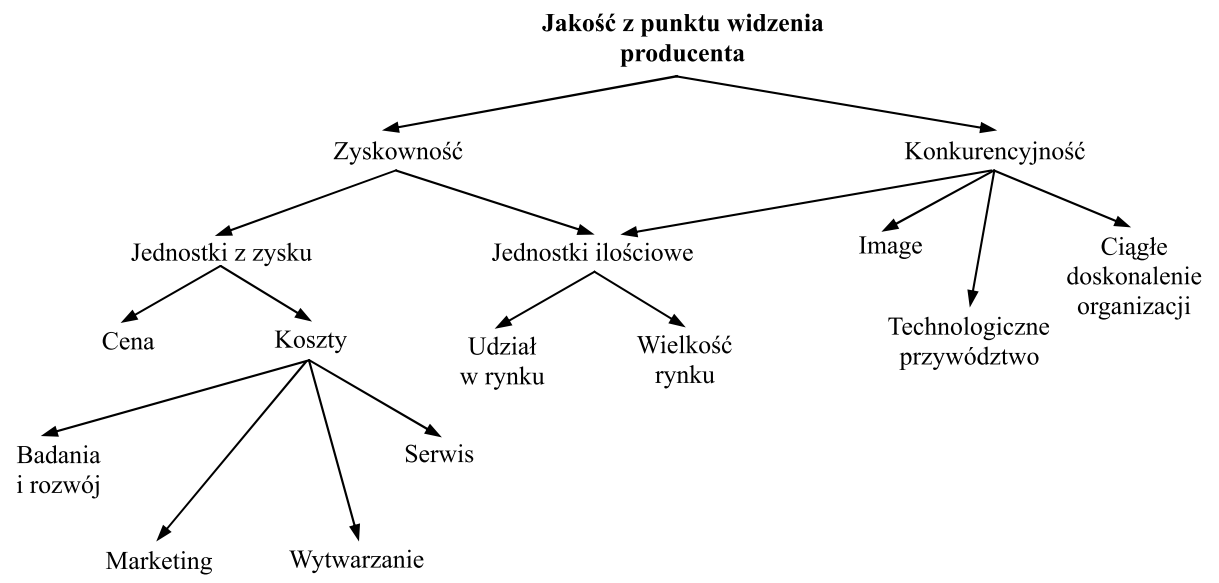

Rys. 5. Jakość z punktu widzenia producenta Źródło: Borucki i Urbaniak 1996

Fig. 5. Quality from the producer's perspective

nabywcom. W związku z tym wyróżnia się pozycjonowanie sektorowe produktu i pozycjonowanie portfelowe produktów.

Opracowując strategię konkurencji w danym sektorze, należy przeprowadzić analizę strukturalną sektora, analizę grup strategicznych oraz wybrać segmenty rynku, na którym zamierza się konkurować (rys. 6).

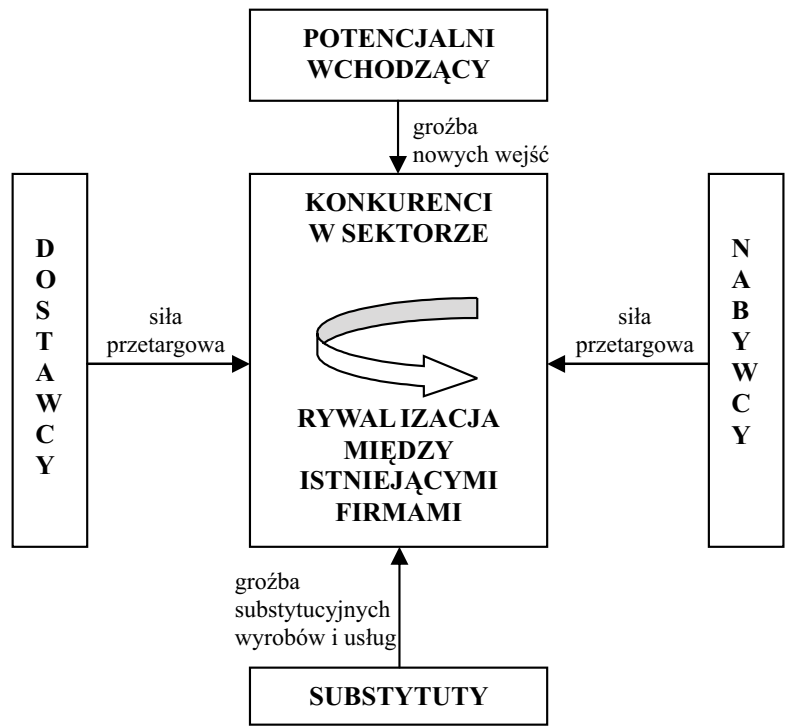

Rys. 6. Pięć sił konkurencyjnych na rynku Źródło: Porter 1998

Fig. 6. Five competitive forces on the market 
Pozycjonowanie portfelowe dotyczy sytuacji, w której przedsiębiorstwo sprzedaje wiele produktów lub wiele asortymentów jednego produktu.

Analizy portfelowe są przedstawione w postaci macierzy, w której jedna oś współrzędnych charakteryzuje wybraną cechę otoczenia, natomiast druga oś współrzędnych charakteryzuje wybraną cechę przedsiębiorstwa, a ściślej - cechę strategicznej jednostki biznesu (SJB). Takimi cechami są np. atrakcyjność rynku, pozycja konkurencyjna SJB itp.

Ilość wydzielonych pól macierzy zależy od skalowania obydwu cech. W polach takich formułowane są zalecenia strategiczne dla przedsiębiorstw. Macierze służą do diagnozowania sytuacji SJB (produktów) poprzez ich lokalizację w polach macierzy oraz do formułowania strategii, czyli decyzji strategicznych w odniesieniu do poszczególnych produktów.

\section{Perspektywa kompetencyjna}

Kompetencje przedsiębiorstwa górniczego, podobnie jak innych przedsiębiorstw, określają trzy wymiary:

- mistrzostwo indywidualne,

- doświadczenie firmy w określonych dziedzinach,

- umiejętność rozwiązywania problemów.

Integracja w perspektywie kompetencyjnej polega na wzbogacaniu własnych kompetencji o nowe kompetencje właściwe nabywanej firmie. Kluczowe kompetencje polegają na właściwym połączeniu zasobów i umiejętności, które (rys. 7):

- zwiększają wartość produktu postrzeganą przez konsumenta (produkt uzyskuje przewagę konkurencyjną),

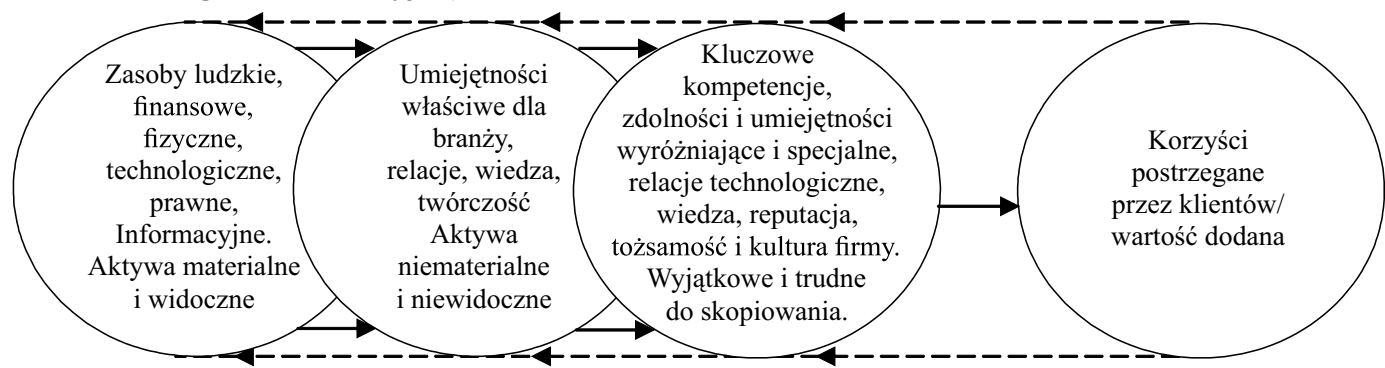

Wkład w procesy firmy Integracja zasobów w działaniach zwiększających wartość

Nie wszystkie umiejętności są kluczowymi, a jedynie te, które dodają większą

wartość niż analogiczne

kompetencje u konkurentów

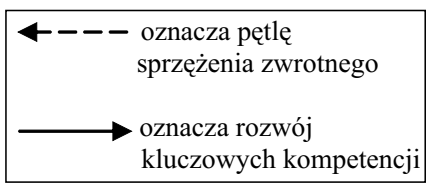

Rys. 7. Relacje pomiędzy zasobami, umiejętnościami i kluczowymi kompetencjami Źródło: Tubielewicz 2004

Fig. 7. Conections between resources, knowledge and key competences 
- są lepsze, tzn. dodają większą wartość niż w przypadku konkurentów,

- są wyraźnie lepsze od kluczowych kompetencji innych organizacji,

- są złożone, trudne do naśladowania - trwale uniemożliwiają skopiowanie lub przejęcie przez konkurentów,

- są wyjątkowe - niedostępne dla konkurentów,

- nie są substytucyjne - nie można ich zastapić inną kombinacją zasobów i umiejętności,

- są dostosowane - mogą zostać wykorzystane w celu uzyskania przewagi konkurencyjnej na innych rynkach,

- są adaptowalne - łatwe do zarządzania i adaptowania.

W ujęciu dynamicznym wyróżnia się następujące poziomy kompetencji (rys. 8):

- poziom wyróżniający cechuje się tym, że konkurencja nie potrafi łatwo skopiować danej kompetencji i dzięki temu daje ona przewagę na rynku oraz pozwala na osiagnnięcie ponadprzeciętnego poziomu rentowności,

- poziom kluczowy oznacza, że kompetencja jest powszechna pośród bezpośrednich konkurentów, ale niezbędna do utrzymania się w danym sektorze; jest ona zazwyczaj związana z cechami charakteryzującymi ten sektor,

- poziom rutynowy cechuje się tym, że kompetencja jest właściwa większości przedsiębiorstw i związana z działaniami, które muszą być wykonane,

- poziom zlecania działalności, której wykonanie jest nieopłacalne (outsourcing).

Istotne znaczenie dla funkcjonowania przedsiębiorstwa mają kompetencje technologiczne obejmujące środki techniczne, procedury ich obsługi oraz ich powiązania organizacyjne. Na przykład w KGHM Polska Miedź SA do kluczowych kompetencji można zaliczyć głębienie szybów w górotworze mrożonym, eksploatację złoża na dużych głębokościach systemami komorowo-filarowymi itp.

W przedsiębiorstwach górniczych, a szczególnie surowcowych, występuje wiele technologii, które zazwyczaj tworzą ciągi technologiczne i organizacyjne, np. górnictwo, przeróbka, hutnictwo, metalurgia. Nową generację tworzą projekty przełomowe oparte na nowych zasadach fizycznych, chemicznych bądź też biotechnicznych, np. zgazowanie węgla (Kozłowski i in. 2008).

Przewaga konkurencyjna

Co wyróżnia nas od konkurentów?

\begin{tabular}{|l|}
\hline $\begin{array}{l}\text { Wyróżniająca } \\
\text { kompetencja }\end{array}$ \\
\hline
\end{tabular}

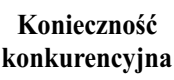

Konieczność

konkurencyjna

Co musimy posiadać, aby móc konkurować?

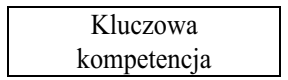

Konieczność wykonania

Jakie rutynowe działania musimy sami wykonywać lub zakontraktować?

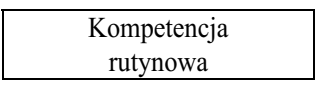

Dzialania niechciane

Jakie działania należy zakontraktować?

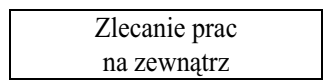

Rys. 8. Dynamiczne ujęcie kompetencj

Źródło: Tubielewicz 2004

Fig. 8. Competences - dynamic approach 
Analizując technologie z punktu widzenia kompetencji, przyjmujemy następującą procedurę (Tubielewicz 2004):

1. Wskazania wszystkich odrębnych technologii i podtechnologii występujących w łańcuchu wartości. Pierwszym etapem formułowania strategii technologicznej jest wskazanie wszystkich technologii i podtechnologii, które wykorzystywane są bądź to przez samą firmę, bądź przez jej konkurentów. Firma musi także zapoznać się z technologiami stanowiącymi element łańcucha wartości jej dostawców i nabywców - często między łańcuchami firmy i jej kontrahentów występują zależności.

2. Wskazanie potencjalnych powiązanych technologii stosowanych $w$ innych branżach lub będących dopiero przedmiotem badań, które można wykorzystać w firmie macierzystej.

3. Określenie prawdopodobnego przebiegu rozwoju najważniejszych technologii. Firma musi ocenić prawdopodobny kierunek zmian technologicznych, jakie zachodzić będą w obrębie każdego działania w łańcuchu wartości przedsiębiorstwa górniczego oraz w łańcuchach jej dostawców i odbiorców.

4. Ustalenie, które technologie oraz potencjalne zmiany technologiczne są najważniejsze dla przewagi konkurencyjnej i struktury branży.

Najważniejsze są przemiany technologiczne, które spełniają następujące kryteria:

- same przyczyniają się do wypracowania przewagi konkurencyjnej,

- zmieniają charakter czynników determinujących koszty lub wyjątkowość na korzyść firmy,

- prowadzą do uzyskania przewag konkurencyjnych we współwystępujących technologiach,

- przyczyniają się do poprawy ogólnej struktury branży.

Najistotniejsze z tego punktu widzenia są technologie mające największy wpływ na koszty będące podstawą trwałego przywództwa technologicznego.

5. Ocena względnego potencjału technologicznego firmy i kosztów wprowadzenia usprawnień. Firma musi znać swoje względnie mocne strony w zakresie technologii oraz dokonać realistycznej oceny swojej zdolności do nadążania za zmianami technologicznymi.

6. Wybór strategii technologicznej, która łączyć będzie wszystkie najważniejsze dla firmy technologie i wspierać ogólną strategię konkurencyjności.

7. Wzmocnienie strategii technologicznych jednostek biznesowych poprzez działania podejmowane na szczeblu korporacyjnym.

\section{Zakończenie}

Strategiczna karta wyników jest metodą zarządzania przedsiębiorstwami, w której formułuje się mierzalne cele powiązane przyczynowo-skutkowo i obejmujące całokształt działalności w różnych obszarach: finansowym, klienta, procesów wewnętrznych i rozwoju. 
Jednocześnie stanowi formę przedstawiania poglądowo strategii $\mathrm{w}$ formie map i tabel ilustrujących cele i ich mierniki oraz powiązania przyczynowo-skutkowe pomiędzy nimi.

W artykule zaproponowano, aby wzorując się na strategicznej karcie wyników dla przedsiębiorstwa, przyjąc ją także jako metodę analizy wybranej części działalności przedsiębiorstwa, np. w obszarze rozwoju. Przyjmując taki punkt widzenia, określamy szczegółowe perspektywy analizy dla wybranej działalności. W artykule zaproponowano, aby w obszarze rozwoju, polegającego na integracji przedsiębiorstw, przyjąć cztery perspektywy analizy: efektywnościową, zasobowa, produktowo-rynkową i kompetencyjną. Wymienione perspektywy analizy, a w szczególności perspektywa zasobowa ma zasadnicze znaczenie dla przedsiębiorstw górniczych przy wyczerpujących się zasobach. Pozostałe perspektywy mają także znaczenie, np. przy rozszerzeniu działalności na inne kraje, regiony i rodzaje kopalin oraz charakterystyki złóż.

Szczególną formą rozwoju przedsiębiorstw górniczych jest integracja przedsiębiorstw górniczych w grupy kapitałowe. Sposobem analizy efektywności takich przedsięwzięć jest zaproponowana w artykule strategiczna karta wyników dla integracji przedsiębiorstw górniczych.

\section{LITERATURA}

Ansoff, H.J. 1965. Corporate Strategy. Analytic Approach to Business Policy for Growth and Expansion. New York: McGraw-Hill Book Co.

Borucki, W. i Urbaniak, M. 1996. Zdefiniować jakość. Problemy Jakości nr 12.

Buckley, A. 2002. Inwestycje zagraniczne-sktadniki wartości i ocena. Warszawa: PWN.

Butra i in. 2010 - Butra, J., Kicki, J., Kudełko, J., Wanielista, K. i Wirth, H. 2010. Strategia zarzqdzania przedsiębiorstwami górniczymi w ujęciu modelowym. Kraków: Wydawnictwo IGSMiE PAN.

Dyczko, A. 2002. Techniczno-ekonomiczne aspekty zubożenia rud miedzi na przykładzie kopalń KGHM Polska Miedź SA Kraków: Wyd. IGSMiE PAN. Gospodarka Surowcami Mineralnymi - Mineral Resources Management t. 18, z. spec.

Fołtyn, W. 2005. Analiza due diligence w integracji przedsiębiorstw. Warszawa: Wydawnictwo Poltext.

Jajuga, K. i Jajuga, T. 1998. Inwestycje. Warszawa PWN.

Johnson, H. 2000. Fuzje i przejęcia. Warszawa: Wydawnictwo LIBER.

Kaplan, R.S. i Norton, D.P. 2006. Strategiczna karta wyników Warszawa: PWN

Kaplan, R.S. i Norton, D.P. 1996. The Balanced Scorecard as a Strategic Management System. HBR, I-II.

Kozłowski, Z. i inni. 2008. Techniczno-ekonomiczny ranking zagospodarowania złóż węgla brunatnego w aspekcie założé polityki energetycznej Polski. Wrocław: Oficyna Wydawnicza PWr.

Krupski, R. i inni.1998. Zarzqdzanie strategiczne. Koncepcje-metody. Wrocław: Wydawnictwo AE.

Kudełko, J. 2009. Strategiczno-ekonomiczna metoda oceny integracji pionowej przedsiębiorstw górniczych. Wrocław: Oficyna Wydawnicza PWr.

Kudełko J. 2011. Analiza due diligence z zakresu ochrony środowiska $w$ transakcjach fuzji i przejęć. Lubin: Wydawnictwo FINESTRA.

Mruk, H. i Rutkowski, J.P. 2001. Strategia produktu. Warszawa: PWE.

Porter, M.E. 1998. Strategia konkurencji. Metody analizy sektorów i konkurentów. Warszawa: PWE.

Sobczyk, J. 2000. Ocena gospodarki zasobami złóż węgla kamiennego metodami taksonomii numerycznej. Kraków: Wyd. IGSMiE PAN Gospodarka Surowcami Mineralnymi - Mineral Resources Management t. 16, z. 3 . 
Suszyński, C. i inni. 2007. Przedsiębiorstwo - wartość zarządzania. Warszawa: PWE.

Tubielewicz, A. 2004. Zarzadzanie strategiczne $w$ biznesie międzynarodowym. Warszawa: Wydawnictwo Naukowo-Techniczne.

Wanielista, K. i inni. 2008. Strategie przedsiębiorstw przemysłowych. Kraków: Wydawnictwo IGSMiE PAN.

Wanielista, K. i Wirth, H. 2008. Wartość i cena złoża. Przeglad Geologiczny vol. 56, nr 7.

Wanielista, K. 2002. Zarządzanie strategiczne przedsiębiorstwami przemysłowymi Kraków: Wyd. IGSMiE

PAN.

STRATEGICZNA KARTA WYNIKÓW W OCENIE INTEGRACJI PRZEDSIĘBIORSTW GÓRNICZYCH

\author{
Słowa kluczowe
}

strategiczna karta wyników, wartość przedsiębiorstwa, wartość złoża, integracja przedsiębiorstw górniczych, rozwój kompetencji

\title{
Streszczenie
}

Strategiczna karta wyników jest jednym z podstawowych narzędzi zarządzania przedsiębiorstwem, którego działalność opisuje się standardowo w perspektywach: finansowej, klienta, procesów wewnętrznych i rozwoju. Przedstawia ona w sposób przyczynowo-skutkowy cele całej działalności przedsiębiorstwa i ich mierniki. Wzorując się na strategicznej karcie wyników stosowanej dla całego przedsiębiorstwa, zaproponowano analogiczną kartę do projekcji i oceny skutków integracji przedsiębiorstw. Integracja przedsiębiorstwa, a szczególnie fuzje i przejęcia są przedsięwzięciami inwestycyjnymi i dotyczą jednego celu strategicznego, tj. rozwoju przedsiębiorstwa. W ramach tej aktywności do badania skutków integracji przedsiębiorstw zaproponowano bardziej szczegółowe obszary (perspektywy) obejmujące zagadnienia efektywności, zasobów, produktów i rynku oraz kompetencji.

W perspektywie efektywnościowej podstawowym miernikiem celu jest wzrost wartości przedsiębiorstwa macierzystego, ale także stosowane są uzupełniająco mierniki statyczne i dynamiczne. Do standardowych mierników statycznych należą wskaźniki rentowności, a do dynamicznych wartość zaktualizowana netto. W perspektywie zasobowej cele integracyjne upatruje się w aktywach geologiczno-górniczych, w szczególności w koncesjach na poszukiwanie, rozpoznanie i użytkowanie złóż. Zasadnicze wymiary oceny plasują się w makroekonomicznej i mikroekonomicznej lokalizacji oraz ocenie geologiczno-górniczej. W perspektywie produktowo-rynkowej cele integracyjne sytuują się w obszarze produktu i polegają na zwiększeniu wolumenu produkcji, wzbogaceniu jego użyteczności w tym cech jakościowych oraz nowych produktach związanych z dywersyfikacją działań. Cele w obszarze rynkowym dotyczą zwiększenia bazy klientów przy czym korzysta się odpowiednio z analiz sektorowych lub portfelowych. Perspektywa kompetencyjna obejmuje wiele obszarów tworzących wiedzę organizacyjną przedsiębiorstwa, na którą składa się mistrzostwo indywidualne, doświadczenie, umiejętność rozwiązywania problemów. Działania, których firma nie może zrealizować samodzielnie, zlecane są na zewnątrz. Zwrócono także uwagę na fakt, że jednym z podstawowych celów integracji przedsiębiorstw jest poszerzenie pola kompetencji. 


\title{
STRATEGIC SCORECARD IN EVALUATION OF MINING COMPANIES INTEGRATION
}

\author{
Key words \\ strategic scorecard, company value, deposit value, integration of mining companies, \\ competences development
}

\section{Abstract}

Strategic scorecard ${ }^{\mathrm{TM}}$ is one of the basic tools in managing the company, which activity is standardly described from several perspectives i.e. finance, client, internal processes and development. It presents, in casually-consecutive way, the targets of company and their measurers. Modelling after the strategic scorecard utilized with regard of entire company, the similar card for projecting and evaluating the results of companies integration, was proposed. Company integration, especially mergers and takeovers are the investment projects and concern, as a whole, one strategic target i.e. the company development. Within that activity, in order to study the results of companies integration, the areas (perspectives) covering the problems of effectiveness, resources, products and market as well as competences, were proposed.

From the perspective of effectiveness the basic target measurer is the increase of parent-company's value but also static and dynamic measurers are used. Among the standard static measures are profitability ratios, while among dynamic ones the net present value (NPV). From resource perspective, the integration targets are sought in mining-geological assets, especially in deposits exploration, prospection and mining concessions (royalties). Essential dimensions of evaluation are positioned within the macroeconomic and microeconomic location and geological and mining estimation. From the product-market perspective, the integration targets are located within the product area and consists in increasing the production volume, improving its usefulness including quality features and new products related with activity diversification. Targets in the market area concern the increase of clients database, whereat the sectorial or portfolio analyses are used respectively. Competence perspective includes many areas building the general organizational knowledge of the company involving individual mastership, experience and problems solving competence. The activities which cannot be made by company itself are contracted outside. It was pointed out that one of the basic targets of companies integration is widening their competence range. 
